\title{
Another Lesson From Beautiful Monsters: the Case of 'sex Reversals' in the Ammonoidea and Their Significance
}

Camile Frau ( $\sim$ camille_frau@hotmail.fr )

Groupement d'Intérêt Paléontologique, Science et Exposition, 35 Impasse lieutenant Daumas 83100 Toulon, France

\section{Pierre-Yves Boursicot}

\section{Research Article}

Keywords: Ammonoidea, Sexual dimorphism, Intersexuality, Pathology, Jurassic

Posted Date: February 2nd, 2021

DOl: https://doi.org/10.21203/rs.3.rs-157754/v1

License: (1) This work is licensed under a Creative Commons Attribution 4.0 International License. Read Full License 


\section{Abstract}

Background: Expression of a sexual dimorphism is recognised in various fossil groups of molluscs such as the Ammonoidea, an extinct group of shelled cephalopods. During the Mesozoic, the best documented sexual dimorphic examples are seen in the Jurassic superfamily Perisphinctoidea. It is most usually expressed by distinct adult size and apertural modifications between the antidimorphs. Putative males (otherwise referred to as microconch) are small in size and develop lappets at the end of the shell while the females (macroconch) are larger and bear a simple peristome. Dubious cases are, however, known in that superfamily. They most often relate to taxonomic biases or lack of diagnostic characters, and some others expose ontogenetic anomalies illustrated by 'sex reversals' in the shell morphology and ornamentation.

Results: The discovery of two specimens of the Callovian Aspidoceratidae Peltoceras athleta (Phillips), having both female and male features, questions the significance and causes of 'sex reversals' in the Ammonoidea. The two specimens have started with the macroconch ontogeny of Peltoceras athleta, and show an apparent change toward maleness in the adult, as illustrated by their rounded whorl section, ribs retroversion, fading of the tubercles and lappets typical of the microconchs. Few other cases of femaleto-male 'sex reversal', as well as male-to-female ones, are known in the fossil record, all belonging to the Jurassic Perisphinctoidea (families Perisphinctidae or Aspidoceratidae). Since all Jurassic Perisphinctoidea are strictly gonochoristic, these 'sex reversals' are pathological in nature and are herein referred to as a new forma-type pathology: namely "forma hermaphrodita".

Conclusions: In the absence of any clear evidence of injury or parasitism, we hypothesize that such "forma hermaphrodita" individuals illustrate pathologic cases of intersexuality. Little is known about the ammonoid soft parts, and it is not possible to determine which internal sexual organs occur in specimen having both male and female external shell features. Abnormal feminisation and/or masculinisation also occur in modern cephalopods; the latter also grouping only gonochoric species. This phenomenon is similarly illustrated by a change in the adult body size and a mixing of both female and male structures. In that case, intersexuality is either advantageous in the population or caused sterility. The causes of intersexuality are not clearly established but environmental pollutants are evoked in modern cephalopods because they act as endocrine disrupters. 'Sex reversals' and/or non-functional reproductive abnormalities have also been caused by endocrine disrupters in various gonochoric gastropods species, but infestation, genetic abnormalities, temperature fluctuations or viruses are multiple causes which can stimulate or inhibit neural-endocrinal activity by direct gonadal influence, and ultimately lead to feminisation or masculinisation in fishes, isopods, crustaceans, and gastropods as well. Regardless of whether "forma hermaphrodita" is due to an exogenic or endogenic cause, the high frequency of intersex Perisphinctoidea in the Jurassic can be explained by the readily recognition of dimorphic pair, and the easy collection of large and sufficiently preserved fossil palaeopopulations in which intersex specimens have statistically more chance to be found.

\section{Background}


Dimorphism of sexual nature have been reported in various fossil groups of molluscs by analogy with recent species. De Blainville (1840) first suggested that sexual dimorphism occurs in the Ammonoidea an extinct group of shelled cephalopods - by comparison with the living nautiloid species

Nautiluspompilius Linnæus, 1758. Nowadays, the presence of a sexual dimorphism in the ammonoids is widely accepted and its palaeobiological criteria are based on: ( $I$ ) a change in shell morphology and aperture; (ii) similar early developmental stages; (iii \& iv) same stratigraphic range and overlapping geographic occurrence; $(v)$ common ancestors; $(v i)$ similar numerical ratio between antidimorphs through time and throughout the evolution of the clade (Klug et al. 2015).

During the Mesozoic, the Jurassic Perisphinctoidea provide the best-known examples of sexual dimorphism (e.g. Makowski 1962; Callomon 1963; Tintant 1963; Westermann 1964a, b; Elmi 1967; Schweigert 1997; Schweigert et al. 2003, 2007; Parent et al. 2008a, b, 2009; Zatoń 2010; Frau et al. 2015, 2016). In this superfamily, the sexual dimorphism is most often expressed by distinct adult size and apertural modifications. Supposed males (otherwise referred to as microconch, $[\mathrm{m}]$ ) are usually small in size, and develop lappets at the end of the growth while the females (macroconch, [M]) are distinctly larger and bear a simple peristome.

However, many sexual dimorphism cases remain dubious due to taxonomic biases and lack of diagnostic features in the adult (Davis et al. 1996). An increase of doubtful cases is observed in the Perisphinctoidea between the Callovian and the Kimmeridgian stages, as the ones listed by BrochwiczLewiński \& Różak (1976). These authors have illustrated apparent 'sex reversals' in the adult shell of various perisphinctoid species known to be dimorphic. The authors thus concluded that these specimens "represent a new type of dimorphism not encountered in other groups of ammonites and that [...] the hypothesis of the sexual dimorphism is not so universal as it was considered to be".

The discovery of two specimens of the Callovian Aspidoceratidae Peltoceras athleta (Phillips, 1829), having both male and female features, questions the significance of these 'sex reversals' in the Ammonoidea.

\section{Materials And Methods}

\section{Origin of the material}

The two specimens of $P$. Athleta, labelled mbe.9305 and mbe.1401 were collected by one of us (P.-Y.B.) in the industrial area of Méron, in the vicinity of Montreuil-Bellay, Maine-et-Loire, France (Fig. 1A-B). There, Bonnot et al. (2005) documented two condensed, oolithic limestone beds of late Callovian age. These beds yield abundant and well-preserved dimorphic-paired ammonite populations (see Bonnot et al., 2005, 2008 , 2014). The studied material originates from the upper limestone bed dated to the Peltoceras athleta Horizon, which characterizes the upper $P$. athleta Zone (Fig. 1C).

\section{Method}


Shell parameters and ornamental features of the two specimens have been compared to the ontogeny and intraspecific variability of the dimorphic species P.athleta documented by Bonnot $(1993,1995)$. Two macroconch (e.g. Athleta Phillips and Baylei Prieser) and two microconch (e.g. Annulosum Quenstedt and Pseudotorosum Prieser) morphotypes of $P$. athleta are recognized by the same author. Typical representatives of the Athleta, Annulosum and Pseudotorosum morphotypes are herein illustrated for comparison (Fig. 2). Bonnot (1995, p. 267-272) provided a detailed biometric database of shell parameters of the four morphotypes based on juvenile and adult specimens from references localities of France and Switzerland. The database is based on standard measurements of the shell, given in millimetres and as percentages of total diameter. The following abbreviations indicate: $D=$ maximum diameter; $\mathrm{Uw}=$ umbilical width; $\mathrm{Wh}=$ whorl height; $\mathrm{Ww}=$ whorl breadth and $\mathrm{K}=$ number of ribs per half $\mathrm{a}$ whorl. The ratios of morphological features (Uw/D, Wh/D, Wb/D and Wb/Wh) and rib density (K/D) to diameter are investigated and compared the dimensions of our specimens (Table 1).

According to Bonnot (1995, p. 272-273), six ornamental stages characterize the $P$. athleta macroconchs (Dmax $240 \mathrm{~mm}$ ): (i) smooth initial whorls with a sub-circular whorl section; (ii) approximated, prorsiradiate, bifurcate and single ribs that cross the venter; (iii) ribs become radial and spaced; (iv) appearance of two lateral tubercles; Whorl section become markedly depressed and trapezoidal; $(v)$ disappearance of intercalate ribs on the venter and $(v i)$ broad single ribs that cross the venter. The microconchs (Dmax $110 \mathrm{~mm}$ ) possess the three first ontogenetic stages of the macroconchs but develop a more circular whorl section. In the microconchs, the fourth stage differs by rectiradiate ribs forming a slight chevron on the venter while the fifth stage develops spaced, strong, rursiradiate, bifurcate ribs approaching a lappeted aperture. The sixth stage is lacking. These stages are herein illustrated in both macro-, and microconchs morphotypes (see Fig. 2).

\section{Results}

\section{shell shape}

The two studied specimens are illustrated on figures 3A and 3B, respectively. Shell shape of specimens mbe.9305 and mbe.1401 is both characterized by a moderate size $(62.3 \otimes \mathrm{D} \otimes 66.6 \mathrm{~mm})$, together with an extremely discoidal (Ww/D 0.33), weakly depressed (Ww/Wh 1.11), very evolute (U/Wh 1.7) subophiocone coiling (Uw/D 0.49). Specimen mbe.9305 is the most complete individual with almost four preserved whorls. Regarding their adult diameter, the two specimens fall in the peak of the normal distribution of the macroconch diameters (Fig. 4A). They are much larger than the P. athletaannulosum microconchs but falls in the normal distribution of the $P$. athletapseudotorosum diameters (Fig. 4B).

Shell parameters of the specimens are compared to the bivariate analysis of the four morphotypes of P.athleta provided by Bonnot (2005). The dimensional parameters growth of the shell (Wh, Ww and Uw as function of $D$ - Fig. $5 A-F$ ) show homogeneous scatters around the mean curve (with $R^{2}$ still very high \pm 0.9 ) in each case. The growth of those parameters is isometric and harmonic and corresponds to the relationship $Y=b D$. Regardless of the shell parameters, specimens mbe.9305 and mbe.1401 have greater 
affinities with the antidimorphs $P$. athletaathleta and $P$. athletapseudotorosum. Only the whorl width index (Ww/D) of the two specimens deviates from that of the two microconch morphotypes, and better fits into the point cloud of the macroconchs (compare Figs. 5C and 5F).

Finally, the subophiocone coiling of specimens mbe.9305 and mbe.1401 compares well to that of the macroconchs, since the microconchs have dactilicone to ophiocone conch shapes, rarely subophiocone (Fig. 5G).

\section{Ornamentation}

The faces of specimen mbe.9305 have similar ornamentation and succession of ontogenetic stages (Fig. 6). This conclusion cannot be reached in specimen mbe.1401 due to poor state of preservation of the right side. No scar or pathological shell compensation is observed exception made of the worn inner whorls. Comparison with the ornamental sequence of both macro-, and microconchs of $P$. athleta is as follows:

- The stage ( $(i)$ is lacking in both specimens. Their ornamentation starts directly with the stage (ii), which occupies one whorl and a half in specimen mbe.9305. This stage is more anarchic in specimen mbe.1401 as illustrated by simple, bifurcate, polygyrate primary ribs, and irregular intercalatories not typical of that stage.

- The stage (iii) is presents in the two specimens and occupies half of a whorl. Ribs are more robust and spaced in specimen mbe.1401. They start to develop slight thickenings at the future emplacement of the tubercles.

- The stages (iv) and ( $v$ ) are typical of $P$. athleta macroconchs and illustrated by strong bituberculate primary ribs, and the progressive disappearance of intercalatories on the venter. It is much longer in specimen mbe.9305 than the other one since it covers one whorl and a half. First peri-umbilical and upper lateral tubercles of the fourth ontogenetic stage are reported at a diameter of $24.3 \mathrm{~mm}$ in the specimen mbe.9305, and $35.4 \mathrm{~mm}$ in the specimen mbe.1401. The boundary between the phragmocone and the body chamber is located at the upper part of the stage (iv) in both specimens. It is at $D \sim 43.2$ in specimen mbe.1401, and at $D \sim 49.4$ in specimen mbe.9305.

- The stage ( $v i)$ is modified in both specimens compared to typical macroconchs. It develops an approximated, strongly flexuous single or bifurcate ribs crossing the venter, and followed by a slightly projected lappeted aperture typical of the microconchs. The section is markedly sub-rounded at the aperture of mbe.1401 and compares well to that of the $P$. athleta microconchs.

According to the criteria of Bonnot (1995), such ornamental sequence conforms well to that of the Peltoceras athleta baylei macroconch morphotype by their long ribbed stage (ii), late appearance of stage (iv) with reduced peri-umbilical tubercles, and persistence of stage $(v)$ in the adult. They, however, develop a sub-rounded whorl section, strong rib retroversion, and a lappet at the end of the shell which are typical features of the $P$. athleta pseudotorosum microconchs. Regarding the number of primary ribs during the 
ontogenesis (Fig. 7A-B), our specimens fall in the variability of the two macroconch morphotypes. The low density of primary ribs on the body chamber excludes these specimens to the rib variability of the $P$. athleta microconchs.

\section{Discussion}

\section{'Sex reversals' in ammonoid shells and definition of a new forma-type pathology}

The species $P$. athleta is widely identified as a dimorphic Aspidoceratidae, including large-sized macroconchs with six ornamental stages and a simple aperture versus small-sized microconchs with lappets and modified/truncated ornamental sequence (Bonnot, 1995, and references therein). The individuals at our disposal start with a female ontogeny typical of the $P$. athleta macroconchs and show an apparent change toward maleness in the adult. The ornamental and dimensional parameters of their phragmocones conform well to those of the $P$. athletabaylei macroconch morphotype, but the adult ornamental modifications better compare to that of the $P$. athletapseudotorosum microconch morphotype (i.e. rounded whorl section, ribs retroversion and fading of the tubercles).

Similar 'sex reversals' have been reported by Brochwicz-Lewiński \& Różak (1976) in the Kimmeridgian dimorphic Perisphinctidae Subnebrodites (pro ldoceras) planula (Hehl) (Fig. 8A). The figured specimen has the shell features of the macroconchs, but it bears a large lip-like peristome typical of the microconchs at the end of the shell. The phenomenon is also reported in the Oxfordian Perisphinctidae dimorphic pair Microbiplices [m] - Ringsteadia [M] by Brochwicz-Lewiński \& Różak (1976), and by Parent et al. (2008a) based on the specimen of Sykes \& Callomon (1979, pl. 121, fig. 9) (Fig. 8B). The figured specimen develops a macroconch sculpture through its growth but has a microconch peristome at the end of the shell. The significance of the apertural structures has been much debated in the literature, but it is now accepted that they correspond to the ultimate stage of sexual maturation of the males (Davis et al. 1996; Klug et al., 2021). A such, the abovementioned specimens illustrate female-to-male 'sexreversals'.

It is worth noting that male-to-female 'sex reversals' are also reported in the fossil record. For example, Cope (1967, p. 16) reported four out of sixty specimens (6\%) of the Kimmeridgian Perisphinctidae Pectinatites (Virgatophinctoides) reisiformis Cope which "appear to be normal macroconchs but have on their inner whorls structures resembling those of the horn of the microconch" (Fig. 9A). Also, fourth Pectinatites specimens are "intermediate in size between the two (micro-and macroconch) groups, [...] have the typical microconch horn developed, but show the beginnings of the macroconch type of ribbing". Another case of male-to-female 'sex reversal' is reported by BrochwiczLewiński \& Różak (1976) based on a specimen of the Oxfordian Perisphinctidae Subdiscosphinctes cracoviensis (Siemiradzki) figured by Méléndez \& Fontana (1993). This specimen displays the onset of macroconch ornamentation [i.e. assigned to the subgenus $S$. (Aureimontanites) or Larcheria], after a youthful peristome typical of the microconchs. The most recent documented case is to be found within the Kimmeridgian Aspidoceratidae dimorphic pair Physodoceras [M] - Sutneria [m] (Parent et al., 2008a) 
(Fig. 9B). These authors illustrated a lappeted specimen of Sutneria subeumela showing a bituberculate sculpture stage in the sub-adult whorls typical for female. In summary, the Mesozoic ammonoids with apparent 'sex reversals, either male-to-female or female-to-male, belong to the superfamily Perisphinctoidea (families Perisphinctidae or Aspidoceratidae) and occur between the Callovian and the Kimmeridgian stages.

Many pathologies modifying the shell geometry and/or ornamentation of ammonoids is documented in the fossil record and classified into categories called forma-types (see review by Hengsbach, 1996). These forma-types usually result of exogenic cause (e.g. sublethal injury, parasitism) and their expression reflect the developmental response of the ammonoids to a perturbation. The study of such 'monsters' has greatly contributed to the understanding of ammonoid evolution and biology in the past decades (Jattiot et al., 2019 and references therein). To our knowledge, no one ever defined a forma-type for ammonoids showing apparent 'sex reversals' during the shell growth. We, therefore, erect a new forma-type pathology here named "forma hermaphrodita" (from Hermaphrodite, the Greek god who displayed both characteristics of male and female). We include the specimens of Brochwicz-Lewiński \& Róża, 1976, Parent et al. (2008a) and the $P$. athleta individuals from Méron in the "forma hermaphrodita" pathology. None of these specimens presents any clear evidence for injury or parasitism although the early whorls are not preserved for further confirmation. Note that the specimen mbe.1401 of P. athleta has anarchic stage (ii) that could pinpoint some perturbations during the early growth.

Based on the published cases listed above, all the individuals referred to as "forma hermaphrodita" belong to perisphinctoid species in which a classic sexual dimorphism is encountered. The rarity of such "forma hermaphrodita" specimens in the fossil record thus pinpoints a pathological nature for explaining these apparent 'sex reversals'.

\section{'Sex reversals' in the Ammonoidea and their significance}

Little is known about the ammonite soft parts (Klug \& Lehmann 2015), and it is not possible to determine which internal sexual organs occur in specimen which has both male and female external shell features. In gonochoric species, the anomalous case of individual possessing gonadal tissue of one sex but exhibits external phenotype of the opposite sex has been previously referred to as pseudohermaphroditism. According to Lee et al. (2006). pseudohermaphroditism is only a manifestation of anomalous sex development among a large mosaic of sex disorders observed in gonochoric species and the term intersexuality should be preferentially used. Considering that the Ammonoidea is a strictly gonochoristic group as the modern cephalopods (Klug et al. 2015), the new "forma hermaphrodita" pathology likely illustrates intersex specimens. This met previous suggestion made by Cope (1967).

The modern cephalopods also group strictly gonochoric species, but external sexual features are generally lacking. The sexual distinction is based on the presence of a hectocotylized arm in males, which transfers the spermatophores to the female. Cases of intersexuality have been reported by Ortiz \& Ré (2006) and Hoving et al. (2006). The abnormal cephalopod specimen of Enteroctopus megalocyathus described by Ortiz \& Ré (2006) is sexed as a female (i.e. absence of the hectocotylus) but shows 
internally male structures with normal genital female characteristics and orientated as in normal octopuses. The authors noticed out that "the presence of mixed female and male structures may not have caused sterility for the female function" (Ortiz \& Ré, 2006, p. 321). The intermediate-sized squid specimens Ancistrocheirus lesueurii described by Hoving et al. (2006), show female nidamental glands in the mantle cavity associated with normally developed male reproductive system. According to the authors, these intersex specimens are common in the population and these 'sex reversals' did "not seem to affect male functionality and is apparently advantageous in that larger body size is accompanied by larger testis and spermatophores".

In these cases, the causes of intersexuality are not clearly established but environmental pollutants arising from human activity are evoked. According to Hoving et al. (2006), environmental pollutants may have conducted to abnormal feminisation and/or masculinisation because they act as endocrine disrupters. 'Sex reversals' and/or non-functional reproductive abnormalities have also been documented in various gonochoric gastropods and linked to endocrine disrupters (Oberdorster \& Cheek 2000). Sexual pathologies in gastropods can also result from the infestation by trematod larvae which stimulate or inhibit neural-endocrinal activity by direct gonadal influence (LeBreton, 1977). This infestation ultimately leads to feminisation or masculinisation. Besides, genetic abnormalities (Hough et al., 1992), temperature fluctuations (Devlin \& Nagahama, 2002) or viruses (Rousset et al. 1992) are mentioned in intersex fishes, isopods and crustaceans as causes for intersexuality.

The Middle to Upper Jurassic transition is not recognised as a critical period for biosphere which had to face deep climatic disturbances, except maybe in the Boreal Realm (Wierzbowsky et al., 2018). This period records a low magnitude, short-term global climate cooling at the Upper Callovian-Middle Oxfordian boundary followed by a subsequent warming in the Upper Oxfordian-Lower Kimmeridgian (Dromart et al., 2003). At that time, the perisphinctoid ammonites became extremely diverse and have colonised a wide range of habitat in different bioprovinces of the world (Schweigert, 2015). Thus, it can hardly be argued that intersexuality in the Perisphinctoidea point to the occurrence of a new reproductive strategy illustrating a veritable hermaphroditism due to changing environmental conditions. Regardless of whether "forma hermaphrodita" is due to an exogenic (infestation, virus) or endogenic cause (genetic abnormalities), the high frequency of intersex Perisphinctoidea in the Jurassic deposits can be explained by the two observations: (1) the readily recognition of dimorphic pair, and (2) the easy collection of large and sufficiently preserved fossil palaeopopulations in which intersex specimens have statistically more chance to be found (see also discussion in Klug et al., 2015, §7.3.7.3).

\section{Conclusions}

We here document a new case of 'sex reversal' in the ammonoid shells, based on two specimens of the Callovian Aspidoceratidae Peltoceras athleta. Those specimens have started with a female ontogeny and show an apparent change toward maleness in the adult. Other cases of female-to-male 'sex reversal', as well as male-to-female 'sex reversal' are known in the ammonoid record, all belonging to the Jurassic superfamily Perisphinctoidea (families Perisphinctidae or Aspidoceratidae). These 'sex reversals' are 
pathological in nature and are herein referred to the new forma-type pathology "forma hermaphrodita".

Regardless of whether "forma hermaphrodita" is due to an exogenic or endogenic cause, those specimens illustrate pathologic cases of intersexuality in the Ammonoidea.

\section{Declarations}

\section{Acknowledgements}

Alain Bonnot (Université de Bourgogne) is gratefully acknowledged for his comments and suggestions on the first version of the manuscript.

\section{Authors' contributions}

CF conceived and designed the study. CF and P-YB interpreted the specimen and its significance, as well as contributed text, figures, and revisions. All authors read and approved the final version of manuscript.

\section{Funding}

Not applicable.

\section{Availability of data and materials}

The Méron specimens are deposited in the private collection of P-YB under collection number mbe.9305 and mbe.1404.

\section{Ethics approval and consent to participate}

Not applicable.

\section{Consent for publication}

Not applicable.

\section{Competing interests}

The authors declare that they have no competing interests.

\section{Author details}

${ }^{1}$ Groupement d'Intérêt Paléontologique, Science et Exposition, 35 Impasse lieutenant Daumas 83100 Toulon, France

${ }^{2} 14$, rue Joannes, FR-49450 Villedieu-la-Blouère, France.

\section{References}


1. Bonnot, A. (1993): Les Peltoceratinae (Ammonoidea) de la sous-zone à Trezeense (Zone à Athleta, Callovien supérieur) en Côte d'Or (France). - Géobios, 26: 135-160.

2. Bonnot, A. (1995): Les Aspidoceratidae d'Europe occidentale au Callovien supérieur et à l'Oxfordien inférieur. 487 pp.; Unpublished PhD thesis University of Burgundy.

3. Bonnot, A., Boursicot, P.- Y. \& Ferchaud, P. (2005): Peltoceras marysae, une nouvelle espèce de Peltoceratinae (Ammonitina, Aspidoceratidae) dans l'horizon à Leckenbyi (Callovien supérieur, zone à Athleta) de Montreuil-Bellay (Maine-et-Loire, France). - Revue de Paléobiologie, 24: 75-95.

4. Brochwicz-Lewiński, W. \&Różak, Z. (1976): Some diffıculties in recognition of sexual dimorphism in Jurassic perisphinctids (Ammoidea). - Acta Paleontologica Polonica, 21: 115-124.

5. Buckman, S. S. (1909-1930):Yorshire Type Ammonites (I-II) and Types Ammonites (III-VII). 709 pp.; Weldon \& Wesley, London.

6. Callomon, J. H. (1963): Sexual dimorphism in Jurassic ammonites. - Transaction Leicester Literature Philosophical Society, 57: 21-56.

7. Cope, J. C. W. (1967): The paleontology and stratigraphy of the lower part of the Upper Kimmeridge Clay of Dorset. - Bulletin of the British Museum of Natural History, 15: 1-79.

8. De Blainville, M. H. (1840): Prodrome d'une monographie des Ammonites. 31 pp.; Nabu Press, Paris.

9. Davis, R. A, Landman, N. H., Dommergues, J.- L., Marchand, D. \& Bucher, H. (1996): Mature modifications and sexual dimorphism in ammonoids. In: Landman, N. H., Tanabe, K. \& Davis, R. A. (Eds.): Ammonoid Paleobiology. Topics in Geobiology. 464-539; New York (Plenum Press)

10. Devlin, R. H. \& Nagahama, Y. (2002): Sex determination and sex differentiation in fish: an overview of genetic, physiological, and environmental influences. - Aquaculture, 208: 191- 364.

11. Dromart, G., Garcia, J.-P., Gaumet, F., Picard, S., Rousseau, M., Atrops, F., Lecuyer, C. \& Sheppard, M. F. (2003): Perturbation of the carbon cycle at the Middle/Late Jurassic transition : geological and geochemical evidence. -American Journal of Science, 303: 667-707.

12. Elmi, S. (1967): Le Lias supérieur et le Jurassique moyen de l'Ardèche. - Documents des Laboratoires de Géologie de Lyon, 19:1-845.

13. Frau, C., Bulot, L. G. \& Wimbledon, W. A. P. (2015): The late Tithonian Himalayitidae (Perisphinctoidea, Ammonitina) from Le Chouet (Drôme, France): systematic implications. Geologica Carpathica, 66: 117-132.

14. Frau, C., Bulot, L. G.n Wimbledon, W. A. P. \& Ifrim, C. (2016): Upper Tithonian ammonites (Himalayitidae Spath, 1925 and Neocomitidae Salfeld, 1921) from Charens (Drôme, France). Geologica Carpathica 67: 543-559.

15. Ghiselin, M.T. (1969): Evolution of hermaphroditism among animals. - Quarterly Review of Biology, 44: 189-208.

16. Hough, A. R., Bannister, N. J. \& Naylor, E. (1992): Intersexuality in the mysid Neomysis integer. Journal of Zoology, 226: 585-588. 
17. Hoving, H. J. T., Roeleveld, M. A. C., Lipinski, M. R. \& Videler, J. J. (2006): Nidamental glands in males of the oceanic squid Ancistrocheirus lesueurii (Cephalopoda: Ancistrocheiridae) - sex change or intersexuality ? - Journal of Zoology, 269: 341-348.

18. Jattiot, R., Fara, E., Brayard, A., Urdy, S. \& Goudemand N. (2019): Learning from beautiful monsters: phylogenetic and morphogenetic implications of left-right asymmetry in ammonoid shells. BMC Evolutionary Biology, 19: 1-13.

19. Jenner, M. G. (1979): Pseudohermaphroditism: a newly recognized sexual phenomenon in llyanassa obsoleta and other Neogastropoda. - Dissertation Abstracts International (B), 40: 1-17.

20. Klug, C. \& Lehmann, J. (2015): Chapter 12 Soft Part Anatomy of Ammonoids: Reconstructing the Animal Based on Exceptionally Preserved Specimens and Actualistic Comparisons. In: Mapes, R. H. (Ed.): From anatomy to ecology: 503 Topics in geobiology, 507-529; Netherlands (Springer).

21. Klug, C., Zatoń, M., Parent, H., Hostettler, B. \& Takija, A. (2015): Chapitre 7 Mature Modifications and Sexual Dimrophism. In: Mapes, R. H. (Ed.): Ammonoid paleobiology: From anatomy to ecology: 503 Topics in geobiology, 253-320; Netherlands (Springer).

22. Klug, C., Schweigert, G., Tischlinger, H. \& Pochmann, H. (2021): Failed prey or peculiar necrolysis? Isolated ammonite soft body from the Late Jurassic of Eichstätt (Germany) with complete digestive tract and male reproductive organs. - Swiss Journal of Palaeontology, 140: 2-14.

23. Lebreton, J. (1977): La sexualité des mollusques gstéropodes et les trématodes parasites. Apport de l'endocrinologie de la sexualité des gastéropodes à l'étude et à l'interprétation des conséquences du parasitisme. In: Premier colloque international de pathologie et parasitologie des mollusques, Haliotis, 8: 215-241.

24. Leckenby, J. (1859): On the Kellaway Rock of the Yorkshire Coast. - Quarternaly Journal of Geological Society of London, 15: 4-15.

25. Lee, P. A., Houk, C. P., Ahmed, S. F. \& Hughes, I.A. (2006): Consensus statement on management of intersex disorders. - Pediatrics, 118: 488-500.

26. Linnæus, C. (1758): Systema naturæ per regna tria naturæ, secundum classes, ordines, genera, species, cum characteribus, differentiis, synonymis, locis. Tomus I, 4 + 824 pp.; Salvius (Editio decima, reformata).

27. Makowski, H. (1962): Problem of sexual dimorphism in ammonites. - Palaeontologia polonica, 12 : $1-143$.

28. Méléndez, G. \& Fontana, B. (1993): Intraspecific variability, sexual dimorphism, and non-sexual polymorphism in the ammonite genus Larcheria Tintant (Perisphinctidae) from the Middle Oxfordian of western Europe. In: House, M. R. (Ed.): The Ammonoidea: environment, ecology, and evolutionary change Systematics Association Special Volume, 165-186; Oxford (Oxford University Press).

29. Oberdorster, E. \& Cheek, A. O. (2001): Gender benders at the beach: Endocrine disruption in marine and estuarine organisms. - Environmental Toxicology and Chemistry, 20: 23-36. 
30. Ortiz, N. \& Ré, M. E. (2006): First report of pseudohermaphroditism in cephalopods. - Journal of Molluscan Studies, 72: 321-323.

31. Parent, H., Scherzinger, H. \& Schweigert, G. (2008a): Sexual phenomena in Late Jurassic Aspidoceratidae (Ammonoidea). Dimorphic correspondence between Physodocerashermanni (Berckhemer) and Sutneria subeumela Schneid, and first record of possible hermaphroditism. Palaeodiversity, 1: 181-187.

32. Parent, H., Schweigert, G., Scherzinger, A. \& Enay, R. (2008b): Pasottia, a new genus of Tithonian oppeliid ammonites (Late Jurassic, Ammonoidea: Haploceratoidea). - Boletín del Instituto de Fisiografía y Geología, 78: 23-30.

33. Parent, H., Greco, A. F. \& Bejas, M. (2009): Size-Shape Relationships in the Mesozoic planispiral ammonites. - Acta Palaeontologica Polonica, 55: 85-98.

34. Phillips, J. (1829): Illustration of the Geology of Yorshire. 192 pp.; London (Wilson Editeur).

35. Tintant, H. (1963): Les Kosmocératidés du Callovien inférieur et moyen d'Europe occidentale. Essai de paléontologie quantitative. 500 pp.; Paris (Presses Universitaires de France).

36. Rousset. F., Bouchon, D., Pintureau, B., Juchault, P. \& Solignac, M. (1992): Wolbachia endosymhionts responsible for various sexual alterations of sexualitv in arthropods. - Proceedings of the Royal Society of London, 250: 1-98.

37. Sykes, R.M. \& Callomon, J. H. (1979): The Amoeboceras zonation of the Boreal Upper Oxfordian. Palaeontology, 22: 839-903.

38. Schweigert, G. (1997): Die Ammonitengattungen Simocosmoceras Spath und Pseudhimalayites Spath (Aspidoceratidae) im süddeutschen Oberjura. - Stuttgarter Beitrage zur Naturkunde, Serie B, 246: 1-29.

39. Schweigert, G. (2015): Chapter 14. Ammonoid Biostratigraphy in the Jurassic. In: Klug C., Korn D., De Baets K., Kruta I. \& Mapes R.H. (Eds.), Ammonoid Paleobiology: From macroevolution to paleobiogeography. Topics in Geobiology, Springer 44, Netherlands: 389-402.

40. Schweigert, G. \& Kuschel, H. (2017): Comments on the identification of Ammonites planula Hehl in Zieten, 1830 (Upper Jurassic, SW Germany). - Volumina Jurassic, XV: 1-16.

41. Schweigert, G., Dietl, G. \& Dietze, V. (2003): Neue Nachweise von Phlycticeras und Oecoptychius (Ammonitina: Strigoceratidae: Phlycticeratinae). - Stuttgarter Beitrage zur Naturkunde, Serie B, 335: $1-21$.

42. Schweigert, G., Dietze, V., Chandler, R. B. \& Mitta, V. (2007): Revision of the Middle Jurassic dimorphic ammonite genera Strigoceras/Cadomoceras (Strigoceratidae) and related forms. - Stuttgarter Beitrage zur Naturkunde, Serie B, 373: 1-74.

43. Westermann, G. E. G. (1964a): Sexual-Dimorphismus bei Ammonoideen und seine Bedeutung fûr Taxinomie der Otoitidae (Einschliesslich Sphaeroceratinae, Ammonitina, M. Jura). Paleontographica, Abteilung A, 124: 33-73.

44. Westermann, G. E. G. (1964b): The ammonite fauna of the Kialagvik formation at Wide Bay, Alaska Peninsula. Part I. Lower Bajocian (Aalenian). - Bulletins of American Paleontology, 47: 327-503. 
45. Wierzbowski, H., Bajnai, D., Wacker, U., Rogov, M.A., Fiebig, J., Tesakova, E. M. (2018): Clumped isotope record of salinity variations in the Subboreal Province at the Middle-Late Jurassic transition. Global and Planetary Change, 167: 172-189.

46. Zatoń, M. (2010): Bajocian-Bathonian (Middle Jurassic) ammonites from the Polish Jura. Part 2: families Stephanoceratidae, Perisphinctidae, Parkinsoniidae, Morphoceratidae and Tulitidae. Palaeontographica abteilung A, 292: 115-213.

\section{Tables}

Due to technical limitations, table 1 is only available as a download in the Supplemental Files section.

\section{Figures}
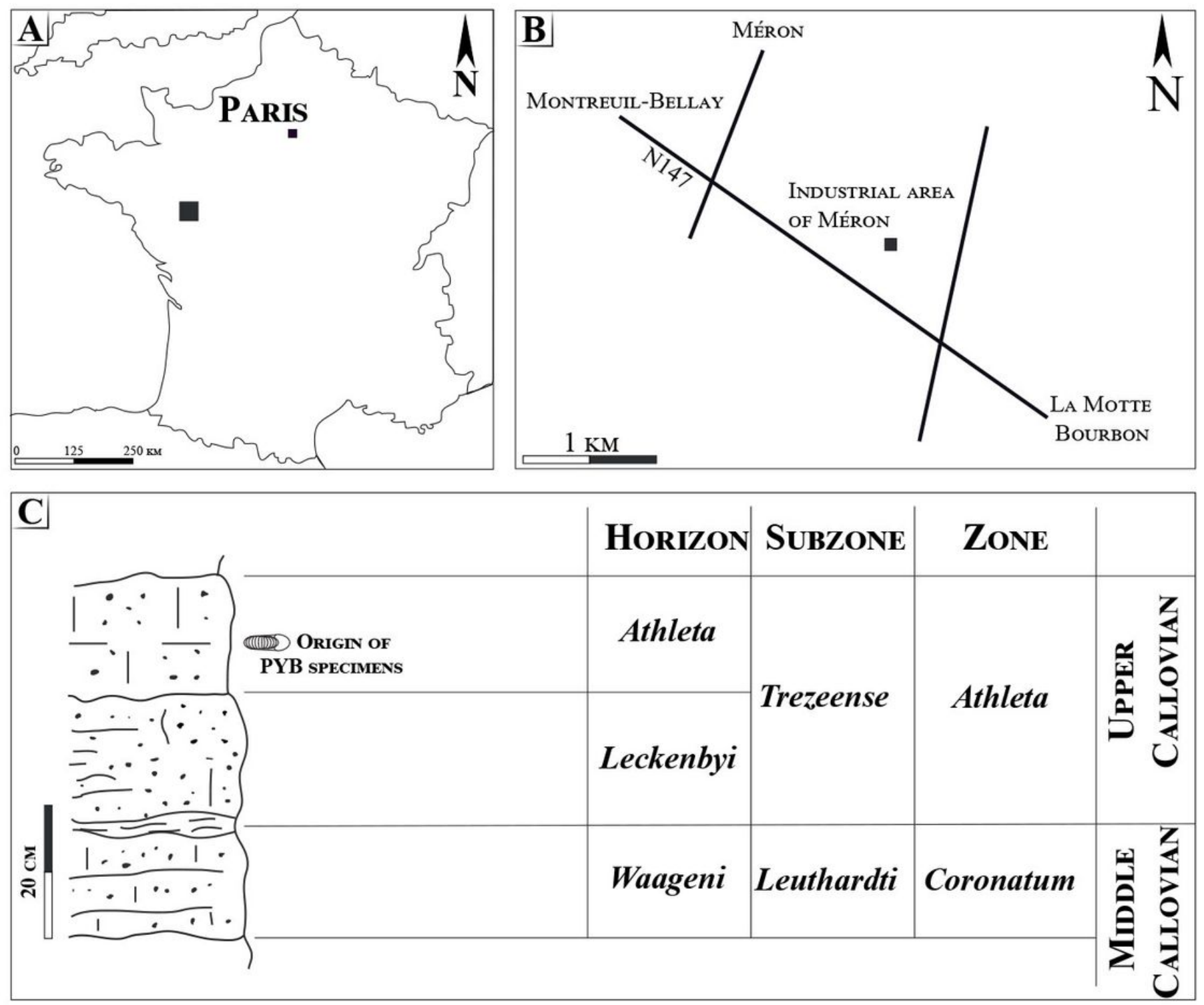

Figure 1 
Location of the Méron locality in the vicinity of Montreuil-Bellay (Maine et Loire, France), and its litho-, and biostratigraphic scheme (modified from Bonnot et al. 2005).

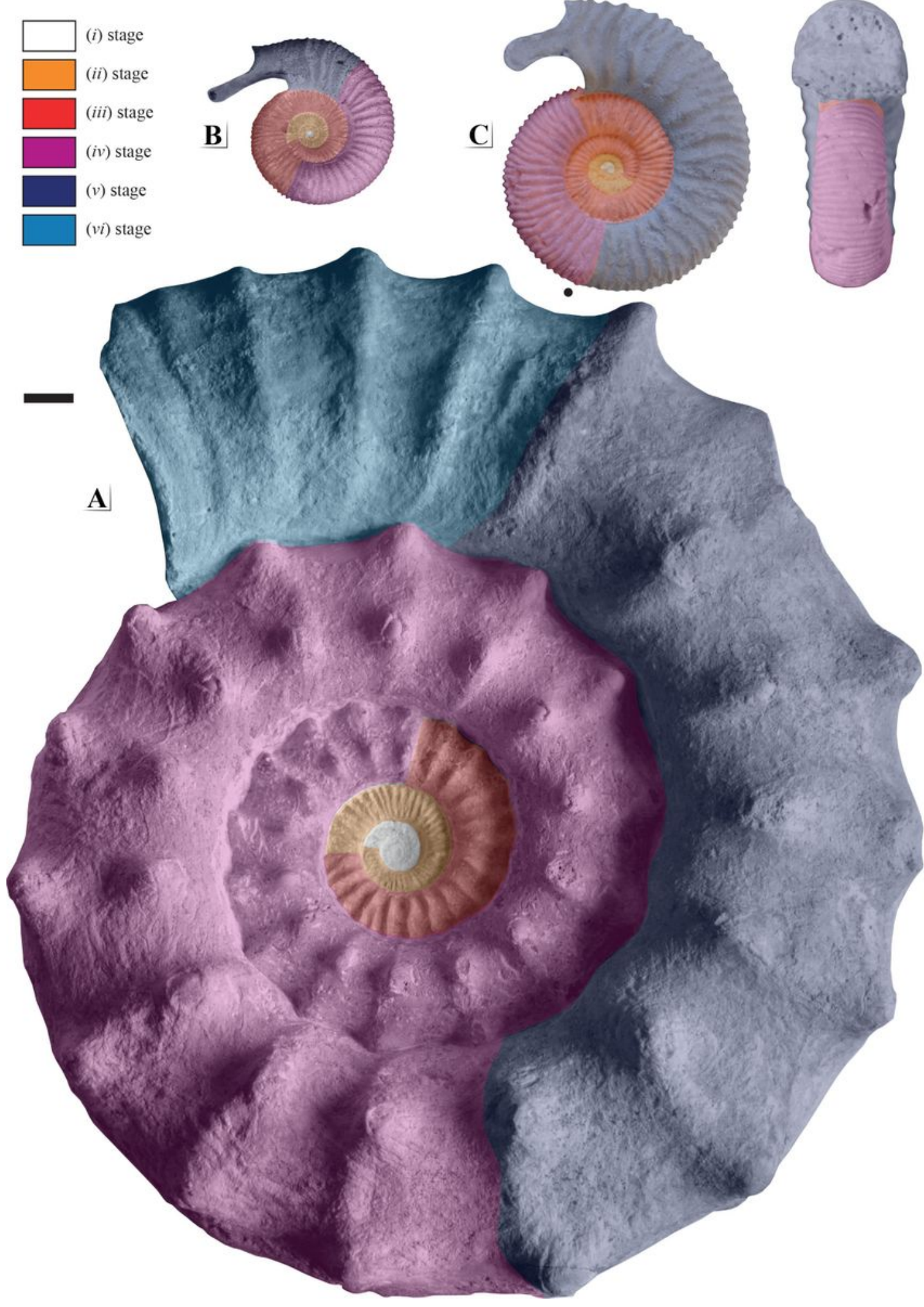

Figure 2

Comparison of selected [m] and [M] morphotypes of Peltoceras athleta: (A) Peltoceras athleta [M]; (B) Peltoceras athleta annulosum [m], (C) Peltoceras athleta pseudotorosum [m], and the six (i to vi) 
ornamental stages defined by Bonnot (1995). All specimens from the Montreuil-Bellay area (PYB collection). Black dots indicate the end of the phragmocone. Scale bar is $10 \mathrm{~mm}$.
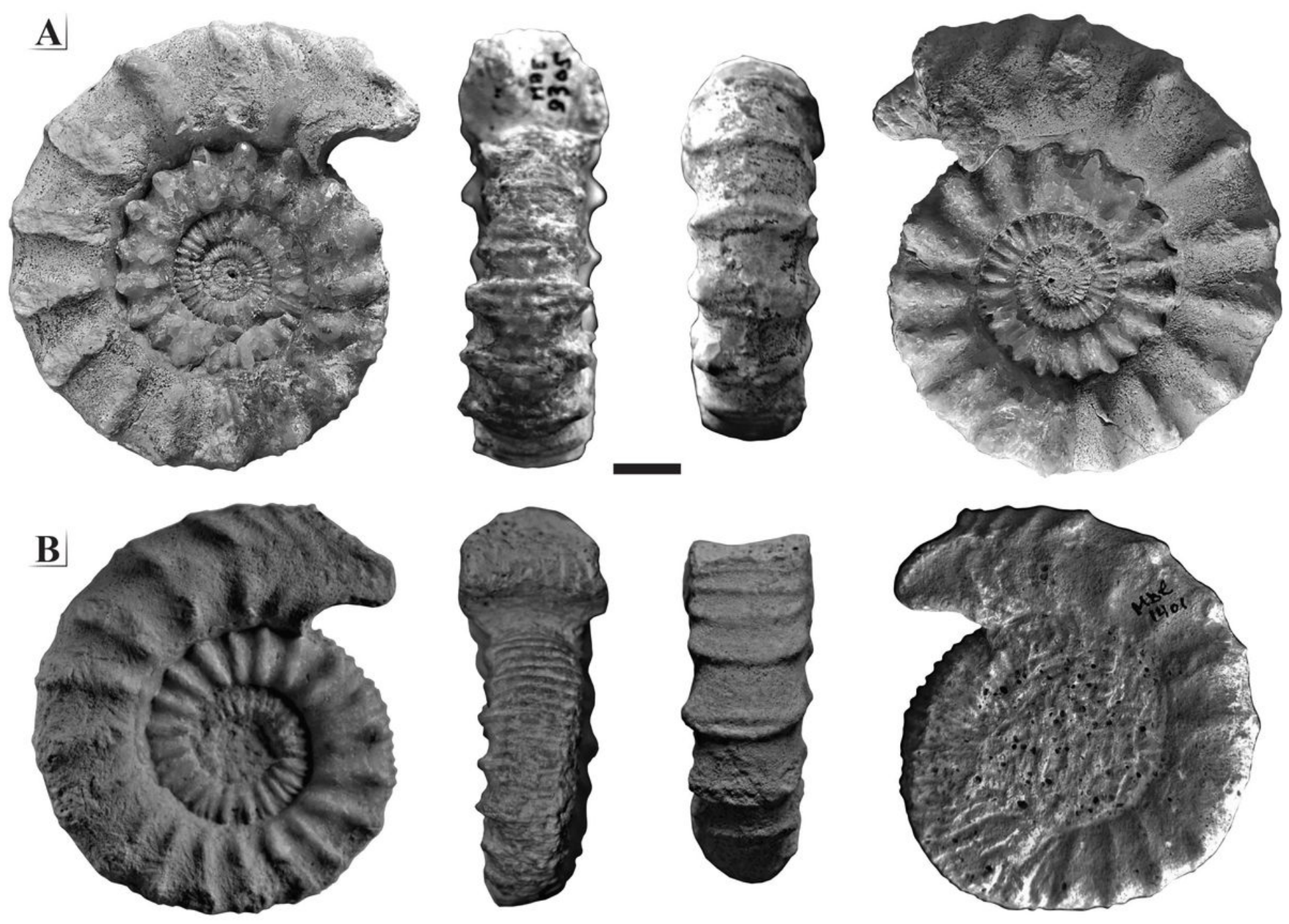

\section{Figure 3}

The anomalous individuals of Peltoceras athleta from the Upper Callovian (P. athleta Zone) of Méron. Lappeted specimens (A: $\mathrm{n}^{\circ}$ mbe.9305; $\mathrm{B}: \mathrm{n}^{\circ}$ mbe.1401; PYB collection) showing a typical macroconch ornamentation on the phragmocone, passing to a microconch-like morphology approaching the aperture. White dots indicate the end of the phragmocone. Scale bar is $10 \mathrm{~mm}$. 


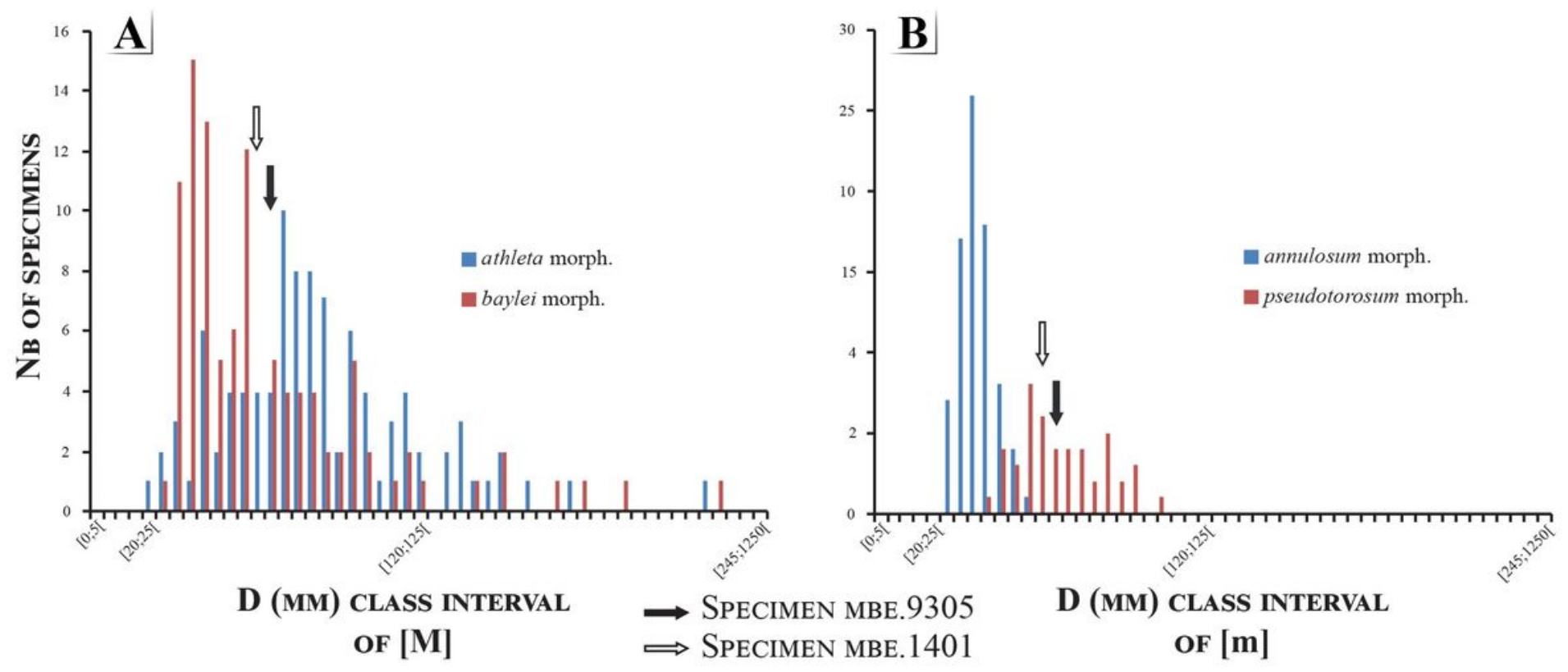

Figure 4

Comparison of specimens mbe.9305 (black arrow), and mbe.1401 (white arrow) with the diameter frequencies of (A) Peltoceras athleta macroconchs, and (B) Peltoceras athleta microconchs databased by Bonnot (1995). 

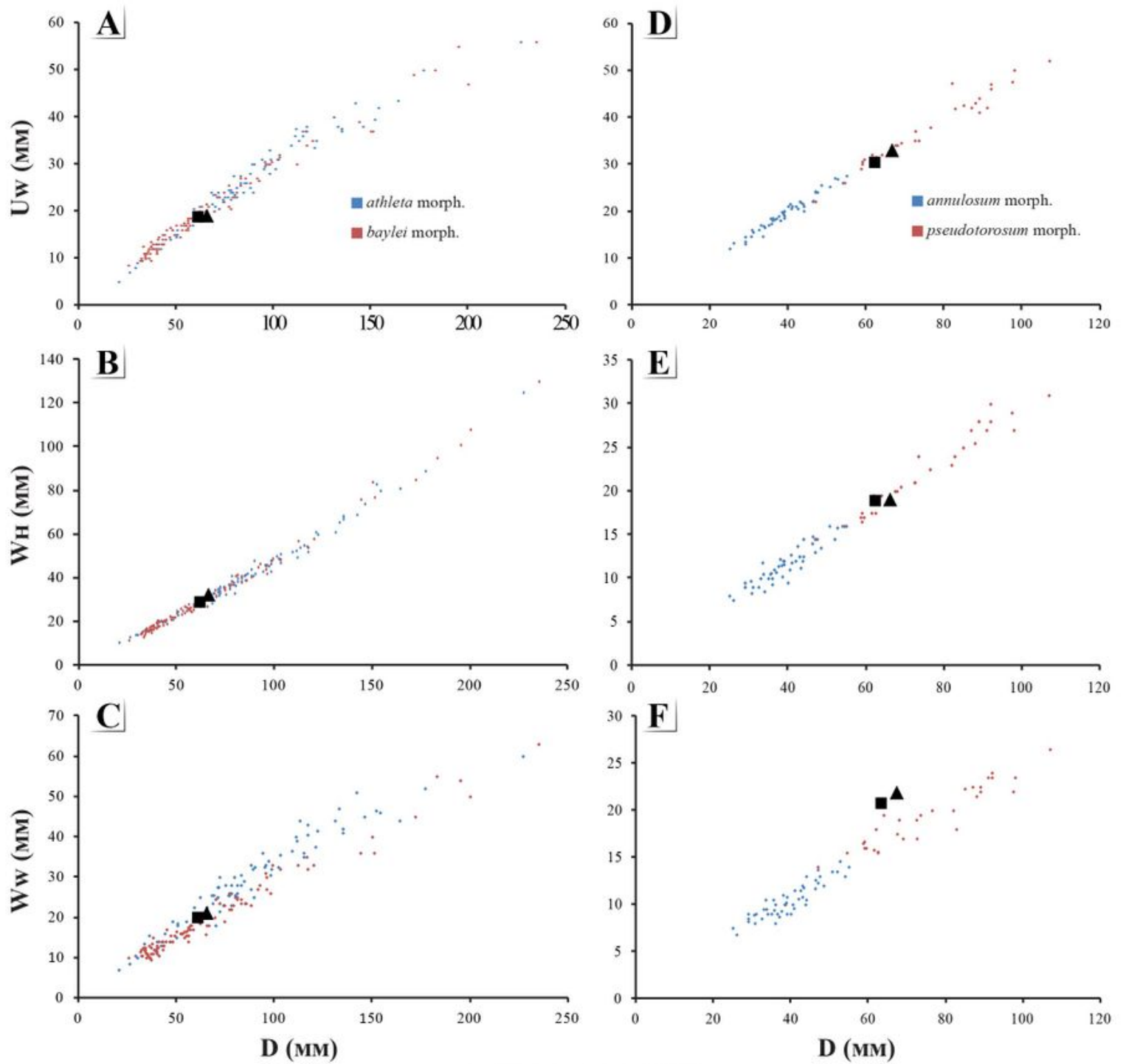

A Specimen mbe.9305

- SPECIMEN MBE.1401

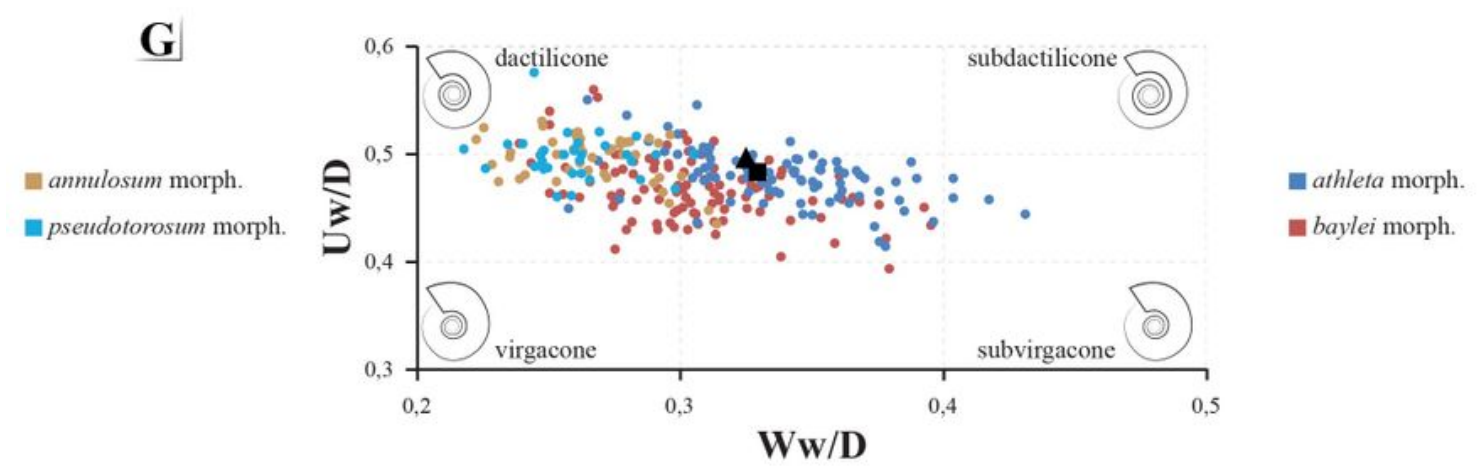

\section{Figure 5}

Comparison of mbe.9305 (black triangle), and mbe.1401 (black square) with dimensional shell parameters of Peltoceras athleta databased by Bonnot (1995). [M]: Variation of the umbilicus length (A); height (B), and thickness of the whorl (C) with the diameter. [m]: Variation of the umbilicus length (D); height $(E)$, and thickness of the whorl $(F)$ with the diameter. $(G)$ compile the coiling variability of both 
Peltoceras athleta macro-, and microconchs databased by Bonnot (1995), and show the position of the studied specimens.
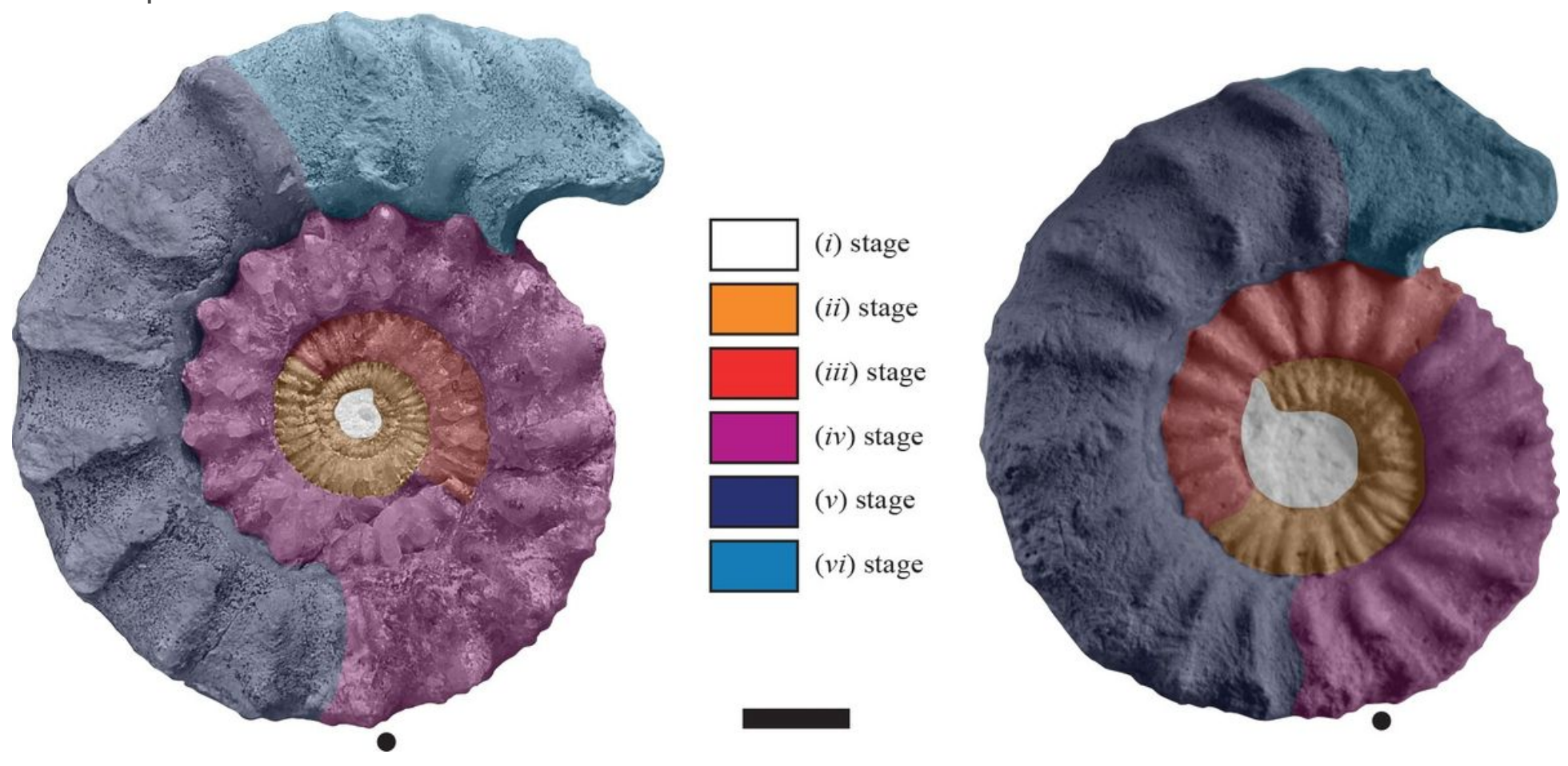

Figure 6

Drawing of the six ornamental stages (i to vi) of Peltoceras athleta as defined by Bonnot (1995) on specimens (A) mbe.9305, and (B): mbe.1401. Black dots indicate the end of the phragmocone. Scale bar is $10 \mathrm{~mm}$.

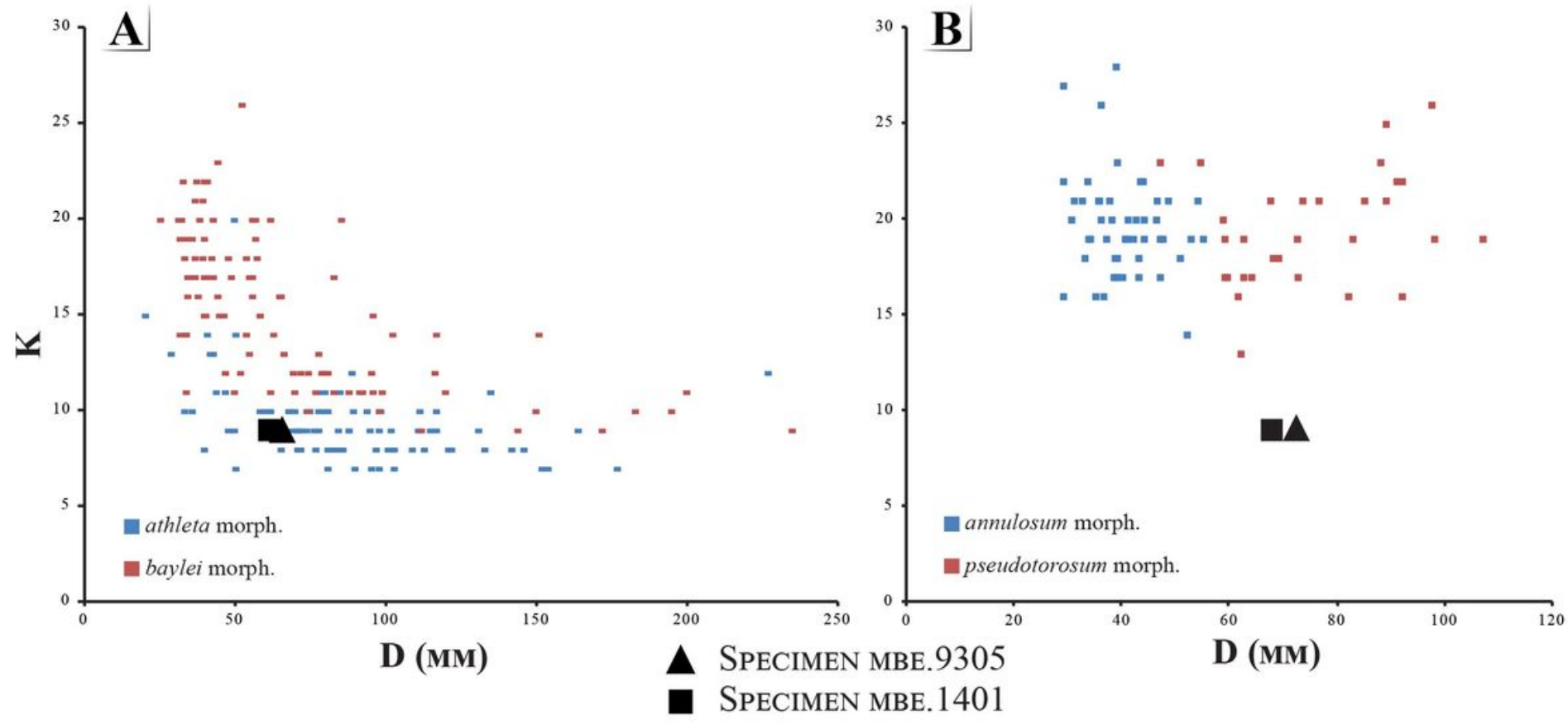

Figure 7 
Comparison of the number of primary ribs with the diameter of mbe.9305 (black triangle), and mbe.1401 (black square) (black triangle) databased by Bonnot (1995): (A) Peltoceras athleta macroconchs [M], and (B) Peltoceras athleta microconchs [m].

A
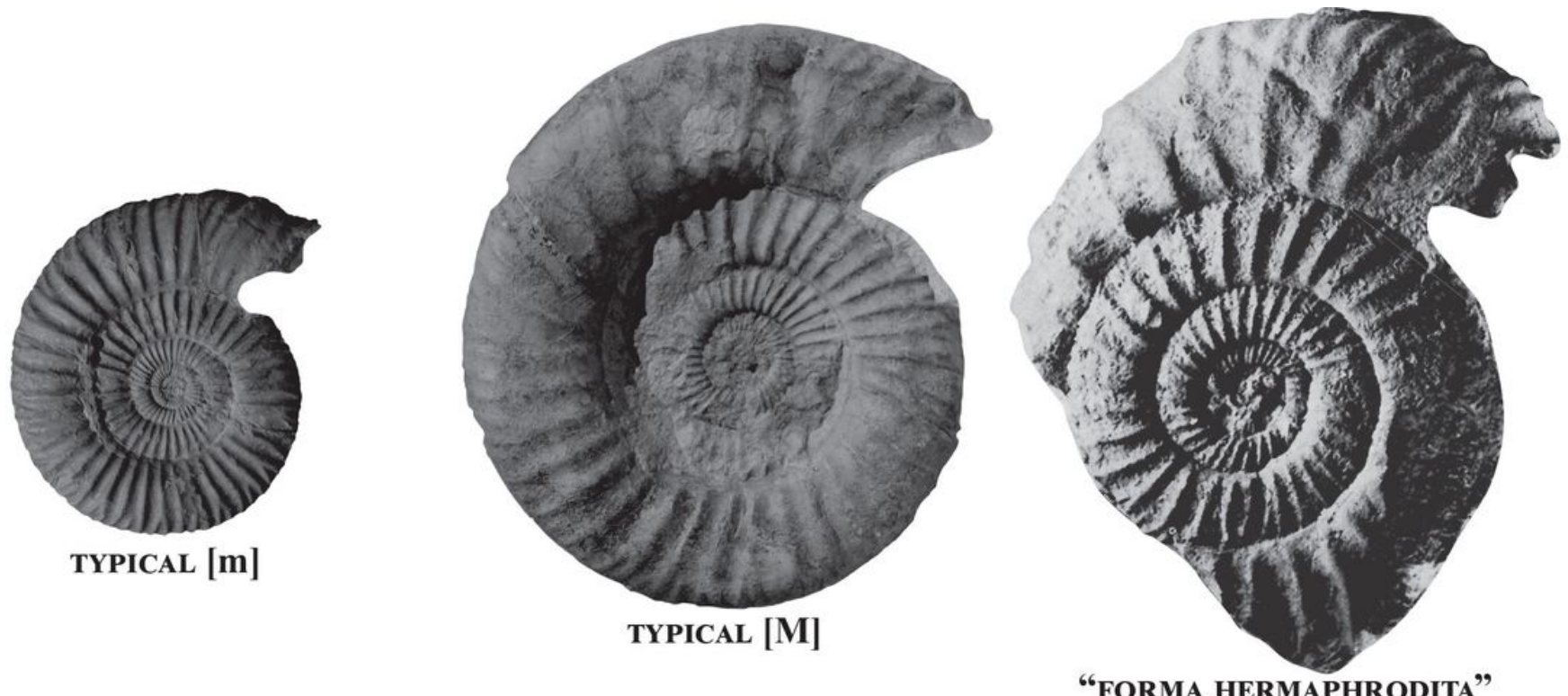

B
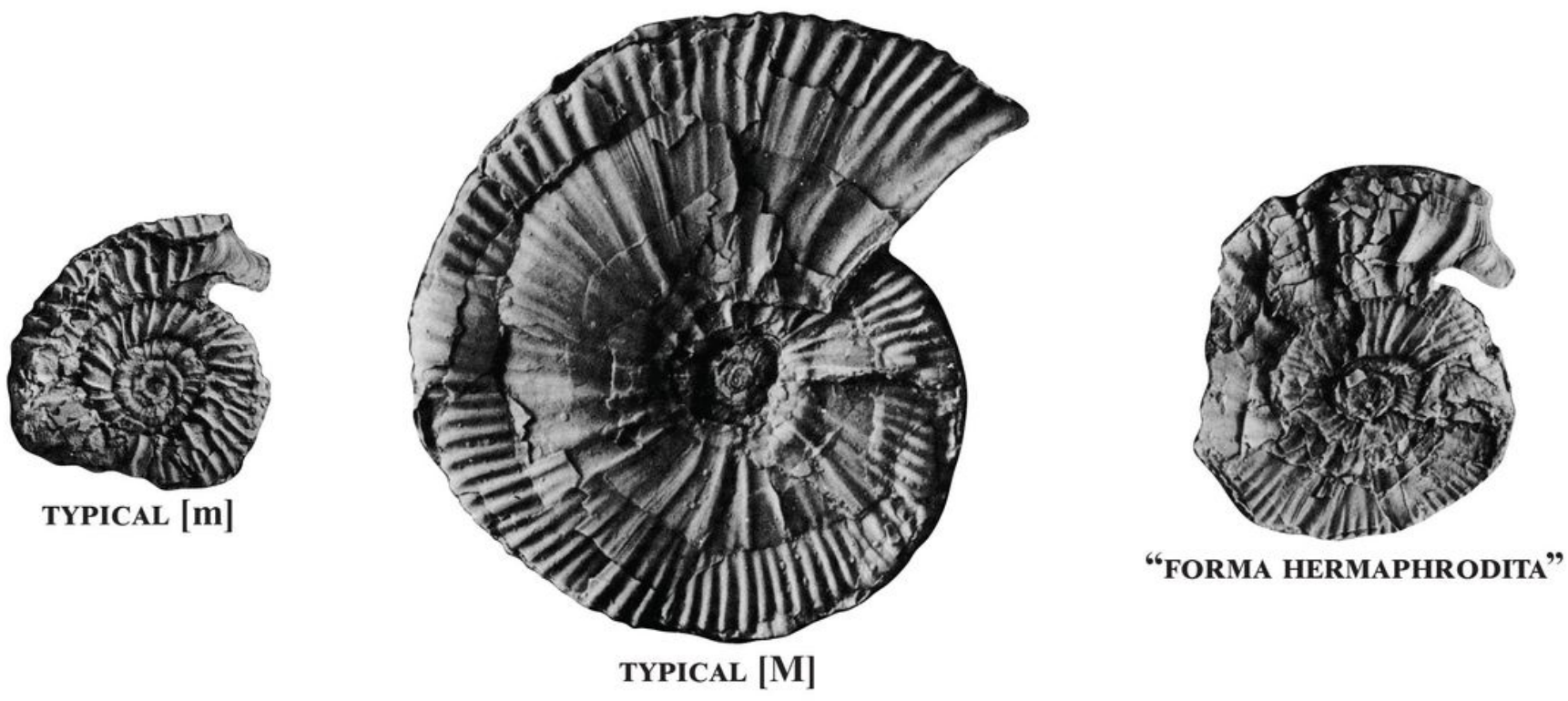

\section{Figure 8}

Illustration of female-to-male "sex-reversals" in the Perisphinctoidea: (A) the Kimmeridgian dimorphic Perisphinctidae Subnebrodites (pro Idoceras) planula (Hehl). Typical [m] and [M] are from Schweigert \& Kuschel (2017) and the "forma hermaphrodita" is from Brochwicz-Lewiński \& Różak (1976); and (B) the Oxfordian Perisphinctidae dimorphic pair Microbiplices [m] - Ringsteadia [M]. All specimens are from Sykes \& Callomon (1979). In both cases, the "forma hermaphrodita" individuals have the shell features of the $[\mathrm{M}]$ but they bear a lappeted peristome typical of the $[\mathrm{m}]$. Specimens are figured using the original scale. 


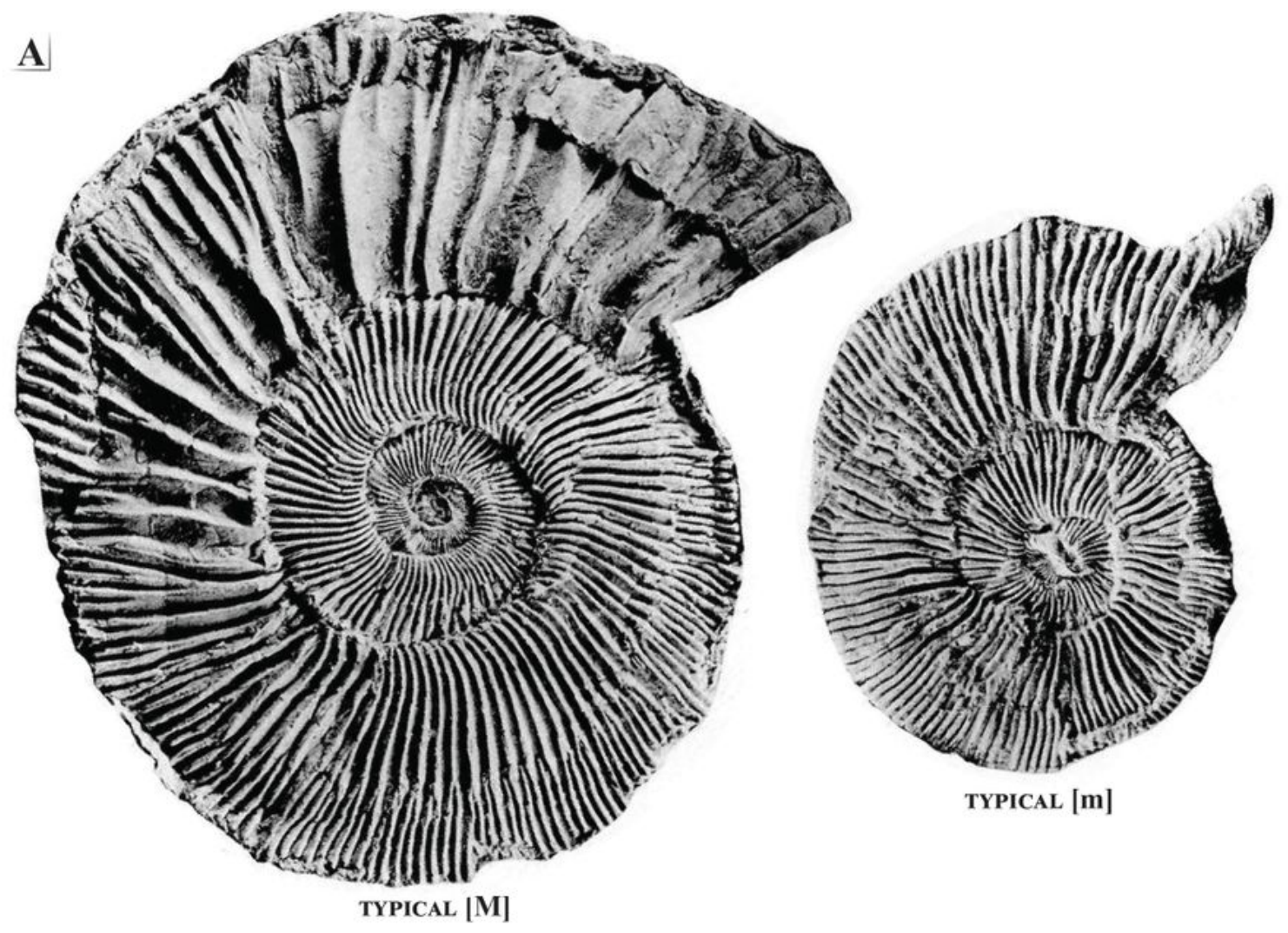

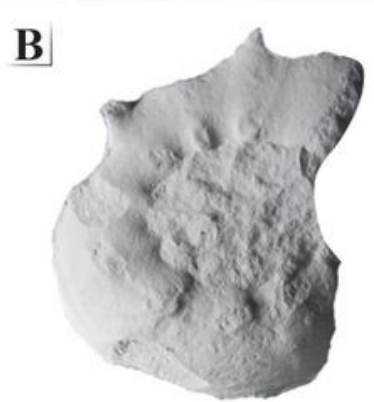

TYPICAL $[\mathbf{M}]$

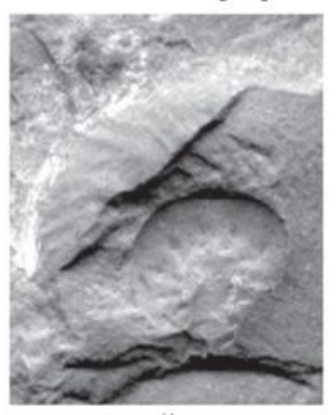

"FORMA HERMAPHRODITA"

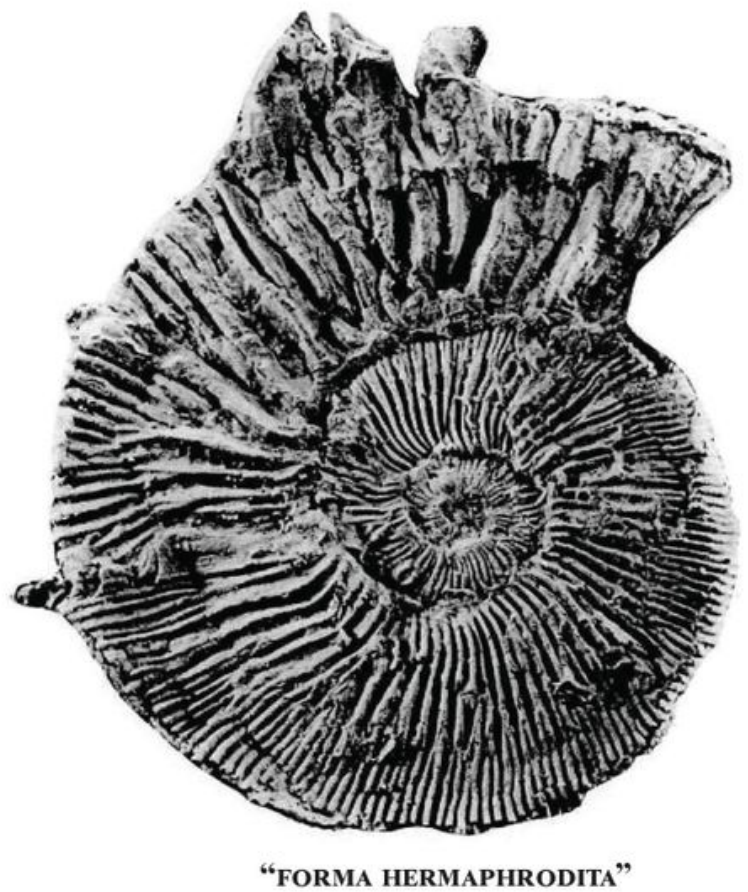

"FORMA HERMAPHRODITA"

Figure 9

Illustration of male-to-female "sex-reversals" in the Perisphinctoidea: (A) the Kimmeridgian dimorphic Perisphinctidae Pectinatites (Virgatophinctoides) reisiformis Cope. All specimens are from Cope (1967); and $(B)$ the Kimmeridgian Aspidoceratidae dimorphic pair Physodoceras [M] - Sutneria [m]. All specimens are from Parent et al. (2008). In (A), the "forma hermaphrodita" individual appears intermediate in size between the [m] and [M], has the sculpture typical of the [M], but sporadically 
develops structures resembling those of the horn of the [m]. In (B), the "forma hermaphrodita" individual starts with a bituberculate sculpture typical for female and develops the ornamentation and lappet typical of the $[\mathrm{m}]$ on the outer whorl. Specimens are figured using the original scale.

\section{Supplementary Files}

This is a list of supplementary files associated with this preprint. Click to download.

- Table1.xlsx 